\title{
Euthanasia in Belgium: trends in reported cases between 2003 and 2013
}

\author{
Sigrid Dierickx MSc, Luc Deliens PhD, Joachim Cohen PhD, Kenneth Chambaere PhD
}

\begin{abstract}
- ABSTRACT
Background: In 2002, the Belgian Act on Euthanasia came into effect, regulating the intentional ending of life by a physician at the patient's explicit request. We undertook this study to describe trends in officially reported euthanasia cases in Belgium with regard to patients' sociodemographic and clinical profiles, as well as decision-making and performance characteristics.
\end{abstract}

Methods: We used the database of all euthanasia cases reported to the Federal Control and Evaluation Committee on Euthanasia in Belgium between Jan. 1, 2003, and Dec. 31, 2013 ( $n=$ 8752). The committee collected these data with a standardized registration form. We analyzed trends in patient, decision-making and performance characteristics using a $\chi^{2}$ technique. We also compared and analyzed trends for cases reported in Dutch and in French.

Results: The number of reported euthanasia cases increased every year, from $235(0.2 \%$ of all deaths) in 2003 to 1807 (1.7\% of all deaths) in 2013. The rate of euthanasia increased significantly among those aged 80 years or older, those who died in a nursing home, those with a disease other than cancer and those not expected to die in the near future $(p<0.001$ for all increases). Reported cases in 2013 most often concerned those with cancer $(68.7 \%)$ and those under 80 years $(65.0 \%)$. Palliative care teams were increasingly often consulted about euthanasia requests, beyond the legal requirements to do so $(p<0.001)$. Among cases reported in Dutch, the proportion in which the person was expected to die in the foreseeable future decreased from $93.9 \%$ in 2003 to $84.1 \%$ in 2013 and palliative care teams were increasingly consulted about the euthanasia request (from $34.0 \%$ in 2003 to $42.6 \%$ in 2013). These trends were not significant for cases reported in French.

Interpretation: Since legalization of euthanasia in Belgium, the number of reported cases has increased each year. Most of those receiving euthanasia were younger than 80 years and were dying of cancer. Given the increases observed among non-terminally ill and older patients, this analysis shows the importance of detailed monitoring of developments in euthanasia practice.
I n 2002, Belgium legalized euthanasia, defined as the intentional ending of life by a physician at the patient's explicit request. ${ }^{1,2}$ For a patient to be eligible for euthanasia, certain formal criteria for due care must be met. ${ }^{1}$ These include a voluntary, well-considered, repeated and written request, expressed by a person with full mental capacity who is fully informed about his or her medical condition and the remaining therapeutic possibilities. ${ }^{1}$ The person must be in a state of constant and unbearable physical or mental suffering that cannot be alleviated. Due care criteria for the procedure include an a priori consultation with a second independent physician, consultation with a third physician in cases where death is not expected in the foreseeable future and a posteriori reporting of the case for evaluation purposes. ${ }^{1}$

To safeguard due process and legal compliance and to enable societal control and evalua- tion, a mandatory notification procedure was built into the legislation. ${ }^{3}$ Physicians are required to report each case of euthanasia to the multidisciplinary Belgian Federal Control and Evaluation Committee on Euthanasia by completing and submitting a registration form within 4 working days after a death by euthanasia. ${ }^{1,3}$ The evaluation committee reviews the form and determines whether euthanasia was performed in accordance with the legal requirements. Initially, only anonymous information is reviewed; where there is doubt about legality, the committee can revoke anonymity by majority decision and can ask the reporting physician for additional information. If the committee is of the opinion, based on a twothirds majority, that the legal requirements were not fulfilled, the case is sent to the public prosecutor. ${ }^{1,3}$ Although not mentioned in the Belgian law, physician-assisted suicide is treated as a form of euthanasia by the committee. ${ }^{4}$
Competing interests: None declared.

This article has been peer reviewed.

Accepted: June 17, 2016 Online: Sept. 12, 2016

Correspondence to: Sigrid Dierickx, sigrid.dierickx@ vub.ac.be

CMAJ 2016. DOI:10.1503/ cmaj.160202 
To facilitate societal control, the Federal Control and Evaluation Committee on Euthanasia is legally required to issue biennial reports of all reported cases, ${ }^{1,3-9}$ providing basic statistics, an evaluation of the law and further recommendations. However, these statistics do not provide an overview of long-term trends. A more complete and thorough evaluation of case characteristics and analysis of trends is needed. In this way, adherence to the legal criteria can be evaluated, and developments in euthanasia practice that might raise concerns can be identified and addressed.

Belgium has 2 main language communities: those who speak Dutch (roughly 60\% of the population), who mainly live in Flanders, and those who speak French (about 40\%), who mainly live in Wallonia. The Brussels-Capital Region is officially bilingual, but predominantly French-speaking. Several empirical studies have found differences in end-of-life practices, knowledge and attitudes between the regions and language communities, showing that Dutchspeaking physicians more often receive and grant euthanasia requests and are more inclined to adhere to legal safeguards. ${ }^{10-14}$ The reports issued by the Federal Control and Evaluation Committee on Euthanasia show a striking disparity in euthanasia reporting between the 2 language communities. ${ }^{4-9}$ Trends in the characteristics of reported cases and differences among them have not yet been studied.

The committee's reports have shown a continuing increase in the number of euthanasia cases. $^{4-9}$ The primary objective of this study was to examine changes in the number and incidence of euthanasia cases and the proportion of euthanasia cases relative to all deaths in Belgium up to and including 2013. The secondary objectives were to determine and report the sociodemographic and clinical characteristics of patients, the decision-making and performance characteristics of reported cases and the differences in trends in characteristics between cases reported in Dutch and cases reported in French.

\section{Methods}

\section{Data source and extraction of data}

We obtained the data presented here from the database of officially reported euthanasia cases in Belgium, made available to us by the Federal Control and Evaluation Committee on Euthanasia. This database contains information routinely collected from the official standardized euthanasia registration forms submitted by the reporting physicians (see Appendix 1, available at www.cmaj.ca/lookup/suppl/doi:10.1503/ cmaj.160202/-/DC1, for the English version of the registration form [authors' translation]). Physicians are contacted by the committee when important information is missing.

We studied all reported cases of euthanasia that occurred between Jan. 1, 2003, and Dec. 31, 2013. Data for euthanasia cases reported in 2014 and 2015 were not included because the committee's summary report for those years had not yet been published. The data are collected for evaluation and control purposes, and the Belgian euthanasia law allows for these data to be made available, on an anonymous basis, for academic research purposes, upon reasonable request to the committee. ${ }^{1}$

The registration form was developed by the Federal Control and Evaluation Committee on Euthanasia and consists of 2 parts. ${ }^{1,3}$ The first part is confidential and includes the identities of the patient, the attending physician and any consultant physicians. The committee may not use this part of the document for evaluation but may decide, by majority, to revoke anonymity and contact the physician for further information in case of irregularities. The second part contains specifications about the age, sex and diagnosis of the person receiving euthanasia, the type of and reasons for the request, the place and date of death, and the euthanasia procedure followed. The committee uses this part to determine whether the performance of euthanasia was in accordance with the conditions and procedures stipulated by law. Further details about the registration form and its items have been described elsewhere. ${ }^{3}$

The registration form contains both openended and closed-ended questions with prestructured response categories. In the database we received, the open-ended questions had been encoded into categories by the committee. We checked the data for coding quality and, if necessary, recoded to obtain consistency over the years in coding of variables. Inconsistencies in the data were checked and clarified with the committee.

\section{Statistical analysis}

Trends in demographic, clinical and decisionmaking characteristics were tested using $\chi^{2}$ linear-by-linear association statistics to calculate bivariable $p$ values. All analyses were performed using SPSS software, version 23.0.

\section{Ethics approval}

Ethics approval is not required for the secondary use of the anonymous data in the database of officially reported euthanasia cases. 


\section{Results}

Between Jan. 1, 2003, and Dec. 31, 2013, a total of 8752 euthanasia cases were reported (Figure 1). The number increased yearly from 235 in 2003 ( $0.2 \%$ of all deaths in that year) to 1807 cases in 2013 (1.7\% of all deaths) (Table 1 ). The proportion of cases of euthanasia among all deaths rose in all patient subgroups and was consistently highest among those with cancer, patients younger than 80 years of age and those dying at home.

Between 2003 and 2013, the proportion of cases involving patients aged 80 years or older increased from $17.0 \%$ to $35.0 \%(p<0.001)$, while the proportion of cases involving those aged 18 to 59 decreased from $34.5 \%$ to $16.5 \%$ $(p<0.001)$ (Table 2). An increasing proportion of euthanasia cases involved people in a nursing home (from $5.1 \%$ to $12.1 \%, p<0.001$ ) and people with a diagnosis other than cancer (from $15.7 \%$ to $31.3 \%, p<0.001$ ), while there were decreases in the proportion of cases involving those dying in hospital (from 52.3\% to $42.6 \%$, $p<0.001)$ and those with a diagnosis of cancer (from $84.3 \%$ to $68.7 \%, p<0.001$ ). The propor- tion of euthanasia cases among those who were expected to die in the foreseeable future decreased from $91.9 \%$ to $85.3 \%(p<0.001)$. An increasing proportion of reported cases involved people with diagnosis of a neuropsychiatric disorder (from $0.8 \%$ to $3.9 \%, p<0.001$ ).

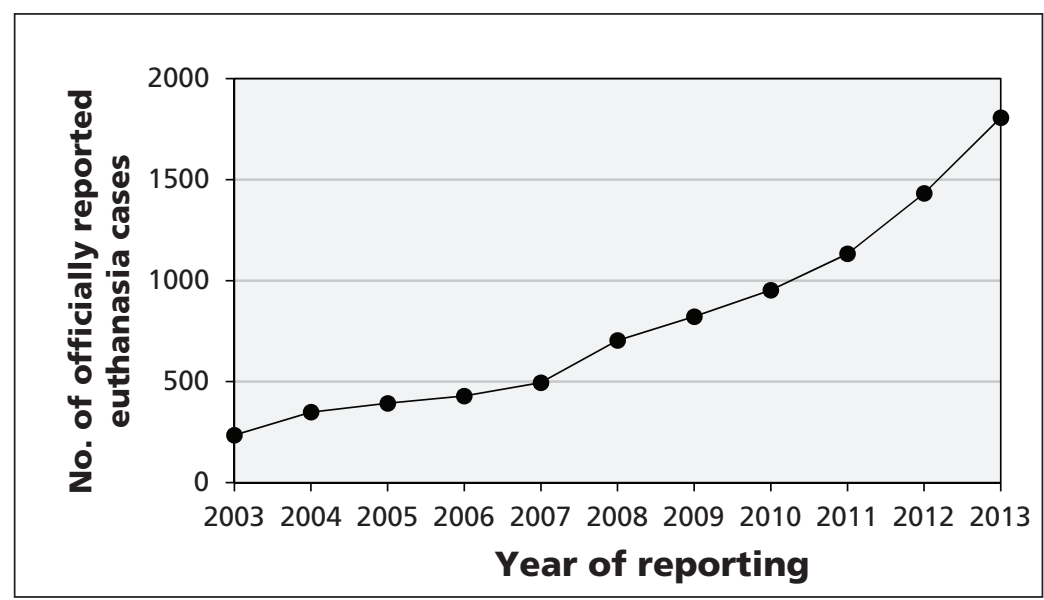

Figure 1: Number of officially reported cases of euthanasia in Belgium, 20032013. Data for 2002 were excluded from the analysis because the euthanasia law came into force on Sept. 23, 2002, ${ }^{15}$ and data for that year thus represent less than an entire year (a total of 24 cases were reported from Sept. 23 to Dec. 31, 2002).

Table 1: Characteristics of deaths in Belgium officially reported as euthanasia, relative to all deaths, 2003-2013*

\begin{tabular}{|c|c|c|c|c|c|c|c|c|c|c|c|}
\hline \multirow[b]{2}{*}{ Characteristic } & \multicolumn{11}{|c|}{ Year; euthanasia cases as $\%$ of all deaths $t$} \\
\hline & 2003 & 2004 & 2005 & 2006 & 2007 & 2008 & 2009 & 2010 & 2011 & 2012 & 2013 \\
\hline $\begin{array}{l}\text { Total no. of } \\
\text { deaths }\end{array}$ & 107039 & 101946 & 103278 & 101587 & 102060 & 104587 & 104509 & 105094 & 104247 & 109034 & 109295 \\
\hline $\begin{array}{l}\text { Incidence of } \\
\text { euthanasia per } \\
100000\end{array}$ & 2.3 & 3.4 & 3.8 & 4.1 & 4.7 & 6.6 & 7.6 & 8.8 & 10.3 & 13.0 & 16.3 \\
\hline Overall & 0.2 & 0.3 & 0.4 & 0.4 & 0.5 & 0.7 & 0.8 & 0.9 & 1.1 & 1.3 & 1.7 \\
\hline \multicolumn{12}{|l|}{ Sex } \\
\hline Male & 0.2 & 0.4 & 0.4 & 0.5 & 0.5 & 0.7 & 0.8 & 1.0 & 1.1 & 1.4 & 1.7 \\
\hline Female & 0.2 & 0.3 & 0.4 & 0.4 & 0.4 & 0.6 & 0.8 & 0.8 & 1.1 & 1.3 & 1.6 \\
\hline \multicolumn{12}{|l|}{ Age, yr } \\
\hline $18-59$ & 0.6 & 0.8 & 0.8 & 1.0 & 1.0 & 1.2 & 1.5 & 1.7 & 1.6 & 2.3 & 2.5 \\
\hline $60-79$ & 0.3 & 0.5 & 0.5 & 0.6 & 0.8 & 1.0 & 1.1 & 1.4 & 1.6 & 1.9 & 2.5 \\
\hline$\geq 80$ & 0.1 & 0.1 & 0.1 & 0.2 & 0.2 & 0.3 & 0.4 & 0.4 & 0.6 & 0.8 & 1.0 \\
\hline \multicolumn{12}{|l|}{ Diagnosis } \\
\hline Cancer & 0.7 & 1.1 & 1.2 & 1.3 & 1.5 & 2.0 & 2.3 & 2.6 & 2.9 & 3.7 & 4.3 \\
\hline $\begin{array}{l}\text { Other } \\
\text { than cancer }\end{array}$ & $<0.1$ & 0.1 & 0.1 & 0.1 & 0.1 & 0.1 & 0.2 & 0.3 & 0.4 & 0.5 & 0.7 \\
\hline \multicolumn{12}{|l|}{ Place of death } \\
\hline Home & 0.4 & 0.5 & 0.6 & 0.7 & 1.0 & 1.2 & 1.5 & 1.8 & 2.1 & 2.4 & 3.1 \\
\hline Hospital & 0.2 & 0.4 & 0.4 & 0.4 & 0.5 & 0.6 & 0.7 & 0.8 & 1.0 & 1.2 & 1.5 \\
\hline Nursing home & 0.1 & 0.1 & 0.1 & 0.1 & 0.1 & 0.2 & 0.2 & 0.2 & 0.4 & 0.5 & 0.8 \\
\hline Other & 0.1 & 0.3 & 0.4 & 0.4 & 0.3 & 0.7 & 1.2 & 0.7 & 0.7 & 0.9 & 0.6 \\
\hline
\end{tabular}


Table 2: Trends in patient characteristics of reported euthanasia cases in Belgium, 2003-2013*

\begin{tabular}{|c|c|c|c|c|c|c|c|c|c|c|c|c|c|}
\hline \multirow[b]{2}{*}{ Characteristic } & \multicolumn{11}{|c|}{ Year; \% of euthanasia cases } & \multirow[b]{2}{*}{$\begin{array}{c}\text { Average } \\
\text { annual } \\
\text { change, \% }\end{array}$} & \multirow[b]{2}{*}{$\begin{array}{c}p \\
\text { valuet }\end{array}$} \\
\hline & $\begin{array}{l}2003 \\
(n= \\
235)\end{array}$ & $\begin{array}{l}2004 \\
(n= \\
349)\end{array}$ & $\begin{array}{l}2005 \\
(n= \\
393)\end{array}$ & $\begin{array}{l}2006 \\
(n= \\
429)\end{array}$ & $\begin{array}{l}2007 \\
(n= \\
495)\end{array}$ & $\begin{array}{l}2008 \\
(n= \\
704)\end{array}$ & $\begin{array}{l}2009 \\
(n= \\
822)\end{array}$ & $\begin{array}{l}2010 \\
(n= \\
953)\end{array}$ & $\begin{array}{l}2011 \\
(n= \\
1133)\end{array}$ & $\begin{array}{c}2012 \\
(n= \\
1432)\end{array}$ & $\begin{array}{l}2013 \\
(n= \\
1807)\end{array}$ & & \\
\hline \multicolumn{14}{|l|}{ Sex } \\
\hline Men & 49.4 & 52.1 & 51.9 & 53.8 & 54.3 & 52.3 & 49.4 & 53.9 & 50.6 & 51.1 & 52.0 & +0.3 & 0.7 \\
\hline Women & 50.6 & 47.9 & 48.1 & 46.2 & 45.7 & 47.7 & 50.6 & 46.1 & 49.4 & 48.9 & 48.0 & -0.3 & 0.7 \\
\hline \multicolumn{14}{|l|}{ Age, yr } \\
\hline $18-59$ & 34.5 & 28.9 & 27.2 & 29.6 & 26.1 & 22.7 & 24.1 & 21.6 & 17.7 & 19.5 & 16.5 & -1.8 & $<0.001$ \\
\hline $60-79$ & 48.5 & 52.4 & 53.4 & 52.2 & 56.8 & 52.6 & 51.1 & 52.4 & 51.6 & 48.5 & 48.5 & 0.0 & 0.006 \\
\hline$\geq 80$ & 17.0 & 18.6 & 19.3 & 18.2 & 17.2 & 24.7 & 24.8 & 26.0 & 30.7 & 32.0 & 35.0 & +1.8 & $<0.001$ \\
\hline \multicolumn{14}{|l|}{ Place of death } \\
\hline Hospital & 52.3 & 55.9 & 51.7 & 52.4 & 47.3 & 47.0 & 43.7 & 44.9 & 44.7 & 45.4 & 42.6 & -1 & $<0.001$ \\
\hline Home & 41.3 & 37.8 & 40.5 & 42.0 & 47.3 & 43.0 & 45.6 & 46.3 & 44.4 & 42.4 & 44.3 & +0.3 & 0.1 \\
\hline Nursing home & 5.1 & 4.3 & 5.6 & 3.0 & 4.2 & 7.8 & 7.4 & 6.3 & 8.9 & 10.4 & 12.1 & +0.7 & $<0.001$ \\
\hline Other & 1.3 & 2.0 & 2.3 & 2.6 & 1.2 & 2.1 & 3.3 & 2.5 & 1.9 & 1.8 & 1.1 & -0.02 & 0.09 \\
\hline \multicolumn{14}{|l|}{ Diagnosis } \\
\hline Cancer & 84.3 & 81.7 & 85.0 & 81.4 & 81.8 & 80.1 & 78.0 & 78.4 & 72.4 & 73.6 & 68.7 & -1.6 & $<0.001$ \\
\hline $\begin{array}{l}\text { Other than } \\
\text { cancer }\end{array}$ & 15.7 & 18.3 & 15.0 & 18.6 & 18.2 & 19.9 & 22.0 & 21.6 & 27.6 & 26.4 & 31.3 & +1.6 & $<0.001$ \\
\hline $\begin{array}{l}\text { Progressive } \\
\text { neuromuscular } \\
\text { disorder }\end{array}$ & 7.8 & 7.7 & 4.3 & 7.5 & 8.7 & 6.1 & 6.4 & 6.8 & 6.9 & 4.9 & 6.3 & -0.2 & 0.1 \\
\hline $\begin{array}{l}\text { Nonprogressive } \\
\text { neuromuscular } \\
\text { disorder }\end{array}$ & 3.0 & 0.3 & 1.5 & 0.2 & 0.8 & 1.1 & 0.6 & 1.0 & 0.5 & 0.8 & 0.4 & -0.3 & 0.009 \\
\hline $\begin{array}{l}\text { Nonmalignant } \\
\text { pulmonary } \\
\text { disorder }\end{array}$ & 0.9 & 1.1 & 3.3 & 2.8 & 1.2 & 2.6 & 3.5 & 1.7 & 3.9 & 2.9 & 3.9 & +0.3 & 0.001 \\
\hline $\begin{array}{l}\text { Cardiovascular } \\
\text { disorder }\end{array}$ & 2.6 & 3.4 & 1.3 & 2.1 & 2.6 & 3.1 & 3.9 & 5.1 & 5.5 & 4.8 & 5.9 & +0.3 & $<0.001$ \\
\hline AIDS & 0.0 & 0.9 & 0.3 & 0.5 & 0.2 & 0.0 & 0.0 & 0.1 & 0.0 & 0.1 & 0.1 & +0.01 & 0.003 \\
\hline Kidney disorder & $\neq$ & $\ddagger$ & 0.0 & 0.9 & 0.2 & 0.4 & 0.6 & 0.3 & 0.6 & 0.8 & 0.7 & +0.07 & 0.02 \\
\hline $\begin{array}{l}\text { Nonmalignant } \\
\text { digestive } \\
\text { disorder }\end{array}$ & $\ddagger$ & $\ddagger$ & 0.3 & 0.0 & 0.0 & 0.6 & 0.2 & 0.3 & 0.5 & 0.5 & 0.6 & +0.03 & 0.007 \\
\hline $\begin{array}{l}\text { Neuropsychiatric } \\
\text { disorder }\end{array}$ & $\ddagger$ & $\neq$ & 0.8 & 1.2 & 0.8 & 1.8 & 2.6 & 2.6 & 2.9 & 3.7 & 3.9 & +0.3 & $<0.001$ \\
\hline $\begin{array}{l}\text { Multiple } \\
\text { pathologies }\end{array}$ & $\ddagger$ & $\neq$ & 2.5 & 0.5 & 2.0 & 1.7 & 2.1 & 1.7 & 2.0 & 4.1 & 5.9 & +0.3 & $<0.001$ \\
\hline Other & 1.3 & 4.9 & 0.8 & 2.8 & 1.6 & 2.4 & 2.1 & 1.9 & 4.8 & 3.9 & 3.7 & +0.2 & 0.001 \\
\hline $\begin{array}{l}\text { Death expected } \\
\text { in foreseeable } \\
\text { future }\end{array}$ & 91.9 & 93.1 & 93.1 & 93.9 & 94.3 & 93.0 & 91.8 & 91.6 & 89.9 & 88.3 & 85.3 & -0.7 & $<0.001$ \\
\hline \multicolumn{14}{|l|}{ Reported suffering } \\
\hline $\begin{array}{l}\text { Physical and } \\
\text { psychologic } \\
\text { suffering }\end{array}$ & 50.6 & 61.2 & 57.0 & 70.7 & 78.2 & 84.6 & 78.0 & 74.2 & 70.0 & 63.5 & 68.5 & +1.8 & 0.5 \\
\hline $\begin{array}{l}\text { Only physical } \\
\text { suffering }\end{array}$ & 42.4 & 34.4 & 37.6 & 27.9 & 20.8 & 13.6 & 18.1 & 22.3 & 26.6 & 28.9 & 27.8 & -1.5 & 0.1 \\
\hline $\begin{array}{l}\text { Only psychologic } \\
\text { suffering }\end{array}$ & 6.9 & 4.4 & 5.4 & 1.4 & 1.0 & 1.9 & 3.9 & 3.6 & 3.4 & 7.5 & 3.7 & -0.3 & 0.03 \\
\hline
\end{tabular}


Over the study period, general practitioners were consulted increasingly often as the second physician (from $34.9 \%$ to $52.4 \%, p<0.001$ ) and disease and organ specialists less often (from $46.0 \%$ to $36.6 \%, p<0.001$ ) (Table 3 ). The proportion of cases in which an additional physician was consulted, beyond the legal requirements for consultation, decreased from $37.9 \%$ to $25.0 \%(p<0.001)$, whereas the proportion of cases in which at least one palliative care team was consulted about the request increased from $33.9 \%$ to $39.3 \%(p=0.001)$.
The use of barbiturates by intravenous administration for euthanasia increased significantly, from $80.0 \%$ to $98.7 \%$ of cases $(p<0.001)$.

Most euthanasia cases were reported in Dutch; the yearly proportion ranged between $79.3 \%$ and $87.1 \%$ of all reported cases over the study period, with a significant decrease over time, from $84.3 \%$ in 2003 to $80.5 \%$ in $2013(p=0.007)$ (data not shown). In 2013, euthanasia cases reported in French, relative to those reported in Dutch, more often occurred in hospital $(52.1 \%$ v. $40.3 \%, p<$ $0.001)$ and less often at home $(38.0 \%$ v. $45.8 \%$,

Table 3: Trends in decision-making and performance characteristics of reported euthanasia cases in Belgium, 2003-2013*

\begin{tabular}{|c|c|c|c|c|c|c|c|c|c|c|c|c|c|}
\hline \multirow[b]{2}{*}{ Characteristic } & \multicolumn{11}{|c|}{ Year; $\%$ of euthanasia cases } & \multirow[b]{2}{*}{$\begin{array}{c}\text { Average } \\
\text { annual } \\
\text { change, \% }\end{array}$} & \multirow[b]{2}{*}{$p$ value } \\
\hline & $\begin{array}{l}2003 \\
(n= \\
235)\end{array}$ & $\begin{array}{l}2004 \\
(n= \\
349)\end{array}$ & $\begin{array}{l}2005 \\
(n= \\
393)\end{array}$ & $\begin{array}{l}2006 \\
(n= \\
429)\end{array}$ & $\begin{array}{l}2007 \\
(n= \\
495)\end{array}$ & $\begin{array}{l}2008 \\
(n= \\
704)\end{array}$ & $\begin{array}{l}2009 \\
(n= \\
822)\end{array}$ & $\begin{array}{l}2010 \\
(n= \\
953)\end{array}$ & $\begin{array}{c}2011 \\
(n= \\
1133)\end{array}$ & $\begin{array}{c}2012 \\
(n= \\
1432)\end{array}$ & $\begin{array}{c}2013 \\
(n= \\
1807)\end{array}$ & & \\
\hline \multicolumn{14}{|c|}{ Type of request for euthanasia } \\
\hline Current request & 99.6 & 98.6 & 98.0 & 96.0 & 98.2 & 98.0 & 97.2 & 97.5 & 97.8 & 96.9 & 98.7 & -0.1 & $>0.9$ \\
\hline Advance directive $\ddagger$ & 0.4 & 1.4 & 2.0 & 4.0 & 1.8 & 2.0 & 2.8 & 2.5 & 2.2 & 3.1 & 1.3 & +0.1 & $>0.9$ \\
\hline \multicolumn{14}{|c|}{ Specialty of second physician§ } \\
\hline $\begin{array}{l}\text { Specialist palliative } \\
\text { care physician }\end{array}$ & 19.1 & 15.5 & 10.7 & 10.0 & 8.7 & 10.1 & 10.4 & 10.2 & 9.6 & 13.8 & 11.0 & -0.8 & 0.3 \\
\hline General practitioner & 34.9 & 41.7 & 42.5 & 44.4 & 48.4 & 46.3 & 51.2 & 49.8 & 50.7 & 50.1 & 52.4 & 1.8 & $<0.001$ \\
\hline $\begin{array}{l}\text { Disease or organ } \\
\text { specialist }\end{array}$ & 46.0 & 42.9 & 46.8 & 45.6 & 42.9 & 43.6 & 38.4 & 40.0 & 39.6 & 36.1 & 36.6 & -0.9 & $<0.001$ \\
\hline \multicolumn{14}{|c|}{ Specialty of third physician, if requiredๆ $(n=867)$} \\
\hline Psychiatrist & 68.4 & 41.7 & 66.7 & 57.7 & 67.9 & 77.6 & 62.7 & 68.8 & 67.9 & 74.3 & 68.9 & 0.1 & 0.06 \\
\hline $\begin{array}{l}\text { Disease or organ } \\
\text { specialist }\end{array}$ & 31.6 & 58.3 & 33.3 & 42.3 & 32.1 & 22.4 & 37.3 & 31.3 & 32.1 & 25.7 & 31.1 & -0.1 & 0.06 \\
\hline \multicolumn{14}{|c|}{ Consultations beyond legal requirements } \\
\hline $\begin{array}{l}\text { Additional physician or } \\
\text { palliative care team }\end{array}$ & 80.3 & 55.3 & 53.9 & 50.6 & 59.2 & 55.5 & 56.0 & 52.4 & 52.3 & 53.3 & 50.7 & -3.0 & $<0.001$ \\
\hline Additional physician & 37.9 & 38.1 & 34.1 & 28.0 & 34.5 & 33.2 & 29.9 & 26.8 & 26.5 & 26.4 & 25.0 & -1.3 & $<0.001$ \\
\hline $\begin{array}{l}\text { Palliative care } \\
\text { team**†† }\end{array}$ & 33.9 & 33.8 & 31.3 & 32.4 & 39.4 & 38.1 & 41.1 & 40.6 & 38.0 & 39.9 & 39.3 & 0.5 & 0.001 \\
\hline \multicolumn{14}{|l|}{ Drugs used* * } \\
\hline $\begin{array}{l}\text { Barbiturate IV, with or } \\
\text { without neuromuscular } \\
\text { relaxant }\end{array}$ & 80.0 & 85.1 & 92.1 & 94.2 & 96.0 & 98.2 & 98.2 & 99.2 & 98.8 & 99.1 & 98.7 & 1.9 & $<0.001$ \\
\hline $\begin{array}{l}\text { Barbiturate per os, } \\
\text { with or without } \\
\text { neuromuscular } \\
\text { relaxant }\end{array}$ & 1.8 & 1.7 & 1.0 & 2.8 & 2.4 & 1.0 & 0.9 & 0.3 & 0.8 & 0.4 & 1.0 & -0.1 & $<0.001$ \\
\hline $\begin{array}{l}\text { Other or unclear from } \\
\text { registration form } \neq \neq\end{array}$ & 18.2 & 13.2 & 6.9 & 3.0 & 1.6 & 0.9 & 1.0 & 0.5 & 0.4 & 0.5 & 0.3 & -1.8 & $<0.001$ \\
\hline
\end{tabular}

Note: IV = intravenous.

*Data for 2002 were excluded from analysis because the euthanasia law came into force on Sept. 23, 2002, ${ }^{15}$ and data for 2002 thus represent less than an entire year. A total of 24 cases were reported from Sept. 23 to Dec. 31, 2002.

tBased on $\chi^{2}$ linear-by-linear association statistics.

\#Euthanasia based on an advance euthanasia directive is allowed only if the person is in an irreversible coma.

$\S$ The attending physician must consult a second, independent physician about the serious and incurable character of the disorder. Information about this aspect is ascertained by an open-ended question on the registration form.

qBelgian law distinguishes between persons who are expected to die in the foreseeable future and those who are not expected to die in the foreseeable future.

For the latter, a third physician must be consulted. The third physician should be either a psychiatrist or a specialist in the patient's illness.

**Data on whether palliative care teams were consulted and on the drugs used to perform euthanasia were available for only 56 of the 235 cases in 2003.

t+Palliative care consultation is not legally required; however, palliative care teams may be consulted about euthanasia requests, beyond the legal requirements to do so.

$\neq$ Other drugs included midazolam, morphine and other drugs used to induce unconsciousness. 
$p=0.009)$. Among cases reported in French, patients were more often expected to die in the foreseeable future than among cases reported in Dutch $(90.1 \%$ v. $84.1 \%, p=0.004)$, physical suffering was more often accompanied by psychologic suffering $(77.0 \%$ v. $66.4 \%, p<0.001)$, and palliative care teams were less often consulted about the request $(25.8 \%$ v. $42.6 \%, p<0.001)$ (data not shown).

Trends in prognosis and in consultation with palliative care teams about the euthanasia request differed between cases reported in Dutch and in French (data not shown). Among cases reported in Dutch, the proportion in which the person was expected to die in the foreseeable future decreased significantly, from $93.9 \%$ in 2003 to $84.1 \%$ in 2013 , and Dutchspeaking physicians increasingly consulted palliative care teams about the euthanasia request (34.0\% of cases in 2003 and $42.6 \%$ in 2013). These trends were not significant for cases reported in French.

\section{Interpretation}

Based on data collected by the Belgian Federal Control and Evaluation Committee on Euthanasia, this study provides insight into trends in the highly debated practice of euthanasia in Belgium. Adding to the data from cross-sectional surveys on Belgian euthanasia practice, ${ }^{16-20}$ the current study provides year-by-year time trends from a population-based perspective for all euthanasia cases officially reported since implementation of the Belgian euthanasia law in 2002. In contrast, recent studies on euthanasia in Belgium have been limited to Flanders, the northern Dutch-speaking part of Belgium. In addition, the current study examines differences in time trends in the reporting of euthanasia between Dutchand French-speaking physicians.

Our analyses showed that the number of officially reported euthanasia cases increased each year (from 235 in 2003 to 1807 in 2013), in both sexes, across all age groups, among those with cancer and diseases other than cancer, and in all care settings. The highest incidence was consistently found among people dying with cancer, those younger than 80 years of age and those dying at home. Among reported cases, the proportions involving patients aged 80 years or older, those dying in a care home setting, those dying of a disease other than cancer and those not having a terminal diagnosis increased, the latter particularly for cases reported in Dutch. Palliative care teams were increasingly consulted about the euthanasia request, beyond the legal requirements to do so, especially for cases reported in Dutch.
Our findings showed an increase in euthanasia among older persons and patients without terminal disease in the most recent years, whereas such cases were relatively rare in the first years of the euthanasia law. These findings might suggest an increase in the number of requests from these groups as they increasingly became aware of the legal possibility to request euthanasia. These findings might also reflect a decrease in reluctance to provide euthanasia within these groups as physicians became more experienced and the wider society became more familiar with these types of cases. We deem it less plausible that the trends indicate more vulnerable groups feeling increasingly forced to choose euthanasia. Moreover, all of the cases included in our analysis were approved by the committee, which implies a careful evaluation of each request without any external pressure.

Given the annual increase in reported cases after legalization in Belgium, as described here, as well as in the Netherlands, ${ }^{21}$ it can be assumed that overburdening of the Belgian review committee may pose a problem, now or in the future. The Dutch review committees have already taken measures to address the increase in reported cases by implementing a new review method, which includes a preliminary screening to separate potentially contentious cases from less contentious cases. ${ }^{22}$ It is desirable that review systems incorporate capacity measures that anticipate increases in reported cases, to guarantee the ability to perform the monitoring function.

The increase in the number of reported euthanasia cases in Belgium is corroborated by a nationwide survey on medical end-of-life practices in Flanders, which found an increase in the euthanasia rate from $1.9 \%$ of all deaths in 2007 to $4.6 \%$ in $2013 .{ }^{17}$ These data suggest an increase in the prevalence of euthanasia and not just in the reporting rate. Our study of reported cases also corroborates the results of that survey showing increases in groups that were previously less likely to request or receive euthanasia, such as older persons and those with diseases other than cancer. ${ }^{17,18}$ The gradual increase in acceptance of euthanasia within society is a likely reason for these changes.

In the early years after legalization, physicians seem to have been more reluctant to grant euthanasia in cases of diseases other than cancer, perhaps because of uncertainty about its legality in such cases. Experience with the practice, reassurance through lack of prosecutions (with the first case since legalization being sent to the public prosecutor for judicial review only in October 2015), media reporting on controversial cases and ensuing public debate about the 
interpretation of legal criteria such as "incurable disorder" and "unbearable physical or psychologic suffering" are likely to have contributed to a broadening of the previously narrow interpretation of the legal criteria. The increase in euthanasia among cases with noncancer diagnoses and nonterminal diseases emphasizes the importance of thorough evaluation and monitoring of the practice, since these situations are often more complex and may include psychiatric disorders and "tiredness of life."

The development of assisted dying has differed from one country to another. The Netherlands, Belgium, Luxembourg, Switzerland, Colombia and 5 American states (Oregon, Washington, Montana, Vermont and California) allow some form of physician-assisted dying. ${ }^{23}$ Official reports from Oregon, Vermont and Washington, where only physician-assisted suicide is legal and euthanasia is not, have also shown an increase in the number of officially reported deaths, although with much lower incidences than in Belgium and the Netherlands. ${ }^{23-28}$ Even within Belgium, development of the practice has differed between Flanders and Wallonia, as our study shows. The relative underrepresentation of reported euthanasia cases from the French-speaking community and the differences in case characteristics corroborate previous studies that found significant differences between Flanders and Wallonia in terms of practice, attitudes and knowledge about euthanasia. ${ }^{10-12,14}$ These differences suggest that euthanasia legislation does not have a predetermined effect on medical end-of-life practice and that social and cultural elements also influence its development.

Several specific factors may have contributed to development of the practice in Flanders. The existence of the Life End Information Forum in Flanders may have led to increased knowledge about euthanasia and standardized procedures in practice by providing advice on assisted dying and other end-of-life issues. ${ }^{29}$ The Life End Information Forum also provides specially trained physicians to act as the legally required second physician, which has been shown to contribute to the careful practice of euthanasia. ${ }^{30,31}$ A similar service, Forum End of Life, has been established in French-speaking Belgium, but it is more limited and less formalized. In addition, palliative care services are involved in Flemish euthanasia practice to a large extent, ${ }^{17}$ offering support during the decision-making process and during the performance of euthanasia. Moreover, the viewpoint of euthanasia as part of the palliative care continuum has been endorsed by the Federation of Palliative Care Flanders. ${ }^{32,33}$
The current study showed an increase in consultation with palliative care teams about the euthanasia request, from $33.9 \%$ of all cases in 2003 to $39.3 \%$ in 2013 . However, the reporting form does not record whether patients have previously received palliative care. Finally, over the years of the study, the topic of euthanasia has received considerable attention in Flemish mainstream media and is an important issue of public debate. ${ }^{34}$

\section{Limitations}

Some limitations must be taken into account. The data provide insight into only those euthanasia cases that were reported. Previous research, conducted in 2007, showed that about half of all euthanasia cases in Belgium were reported to the committee and that unreported cases were generally dealt with less carefully than reported cases. ${ }^{35}$ In addition, this study was based on an analysis of secondary data collected as part of the mandatory notification procedure. Details about the patients' clinical circumstances and the precise nature of the suffering that caused them to seek euthanasia were not recorded in the database.

\section{Conclusion}

The practice of euthanasia in Belgium has increased year by year since the introduction of legislation in 2002. An increase in cases often considered as more controversial, such as those involving neuropsychiatric conditions, has also occurred, although such cases remain a small minority.

Given differences in developments between jurisdictions and even within Belgium, it is clear that societal and cultural contexts play a key role in how euthanasia practice has been adopted after legalization. Our analysis has shown the importance of detailed monitoring of euthanasia practice, provides relevant insights for evaluation of the practice and can inform the debate about euthanasia worldwide.

\section{References}

1. The Belgian Act on Euthanasia of May, 28th 2002. Ethical Perspect 2002;9:182-8.

2. Deliens L, van der Wal G. The euthanasia law in Belgium and the Netherlands. Lancet 2003;362:1239-40.

3. Smets T, Bilsen J, Cohen J, et al. The medical practice of euthanasia in Belgium and The Netherlands: legal notification, control and evaluation procedures. Health Policy 2009;90:181-7.

4. Sixth report to Parliament: January 1, 2012-December 31, 2013 [report in Dutch]. Brussels (Belgium): Federal Control and Evaluation Committee on Euthanasia; 2014. Available: http:// overlegorganen.gezondheid.belgie.be/sites/default/files/documents/ federale_controle_en_evaluatiecommissie_euthanasie/19097638. pdf (accessed 2016 Sept. 2).

5. First report to Parliament: September 22, 2002-December 31 , 2003 [report in Dutch]. Brussels (Belgium): Federal Control and Evaluation Committee on Euthanasia; 2004. Available: http:// overlegorganen.gezondheid.belgie.be/sites/default/files/documents/ federale_controle_en_evaluatiecommissie_euthanasie/14276508. pdf (accessed 2016 Sept. 2). 
6. Second report to Parliament: January 1, 2004-December 31, 2005 [report in Dutch]. Brussels (Belgium): Federal Control and Evaluation Committee on Euthanasia; 2006. Available: http:// overlegorganen.gezondheid.belgie.be/sites/default/files/documents/ federale_controle_en_evaluatiecommissie_euthanasie/14088500.pdf (accessed 2016 Sept. 2).

7. Third report to Parliament: January 1, 2006-December 31, 2007 [report in Dutch]. Brussels (Belgium): Federal Control and Evaluation Committee on Euthanasia; 2008. Available: http:// overlegorganen.gezondheid.belgie.be/sites/default/files/documents/ federale_controle_en_evaluatiecommissie_euthanasie/14280500.pdf (accessed 2016 Sept. 2).

8. Fourth report to Parliament: January 1, 2008-December 31, 2009 [report in Dutch]. Brussels (Belgium): Federal Control and Evaluation Committee on Euthanasia; 2010. Available: http:// overlegorganen.gezondheid.belgie.be/sites/default/files/documents/ federale_controle_en_evaluatiecommissie_euthanasie/19063733.pdf (accessed 2016 Sept. 2).

9. Fifth report to Parliament: January 1, 2010-December 31, 2011 [report in Dutch]. Brussels (Belgium): Federal Control and Evaluation Committee on Euthanasia; 2012. Available: http:// overlegorganen.gezondheid.belgie.be/sites/default/files/documents/ federale_controle_en_evaluatiecommissie_euthanasie/19078961.pdf (accessed 2016 Sept. 2).

10. Cohen J, Van Wesemael Y, Smets T, et al. Cultural differences affecting euthanasia practice in Belgium: one law but different attitudes and practices in Flanders and Wallonia. Soc Sci Med 2012;75:845-53.

11. Smets T, Cohen J, Bilsen J, et al. Attitudes and experiences of Belgian physicians regarding euthanasia practice and the euthanasia law. J Pain Symptom Manage 2011;41:580-93.

12. Smets T, Cohen J, Bilsen J, et al. The labelling and reporting of euthanasia by Belgian physicians: a study of hypothetical cases. Eur J Public Health 2012;22:19-26.

13. Chambaere K, Bilsen J, Cohen J, et al. Differences in performance of euthanasia and continuous deep sedation by French- and Dutchspeaking physicians in Brussels, Belgium. J Pain Symptom Manage 2010;39:e5-7.

14. Van den Block L, Deschepper R, Bilsen J, et al. Euthanasia and other end-of-life decisions: a mortality follow-back study in Belgium. BMC Public Health 2009;9:79.

15. Nys H. Euthanasia in the low countries: a comparative analysis of the law regarding euthanasia in Belgium and the Netherlands. Ethical Perspect 2002;9:73-85.

16. Deliens L, Mortier F, Bilsen J, et al. End-of-life decisions in medical practice in Flanders, Belgium: a nationwide survey. Lancet 2000;356:1806-11

17. Chambaere K, Vander Stichele R, Mortier F, et al. Recent trends in euthanasia and other end-of-life practices in Belgium. $N$ Engl J Med 2015;372:1179-81.

18. Dierickx S, Deliens L, Cohen J, et al. Comparison of the expression and granting of requests for euthanasia in Belgium in 2007 vs 2013. JAMA Intern Med 2015;175:1703-6.

19. Chambaere K, Bilsen J, Cohen J, et al. Physician-assisted deaths under the euthanasia law in Belgium: a population-based survey. CMAJ 2010;182:895-901

20. Bilsen J, Cohen J, Chambaere K, et al. Medical end-of-life practices under the euthanasia law in Belgium. $N$ Engl J Med 2009;361:1120-1.

21. Annual report 2015 [report in Dutch]. The Hague (The Netherlands): Regional Euthanasia Review Committees; 2016. Available: https://www.euthanasiecommissie.nl/uitspraken/ jaarverslagen/2015/april/26/jaarverslag-2015 (accessed 2016 Sept. 2).

22. Annual report 2012 [report in Dutch]. The Hague (The Netherlands): Regional Euthanasia Review Committees; 2013. Available: https://www.euthanasiecommissie.nl/de-toetsings commissies/uitspraken/jaarverslagen/2012/nl-en-du-fr/nl-en-du -fr/jaarverslag-2012 (accessed 2016 Sept. 2).

23. Dyer O, White C, García Rada A. Assisted dying: law and practice around the world. BMJ 2015;351:h4481.
24. Steck N, Egger M, Maessen M, et al. Euthanasia and assisted suicide in selected European countries and US states: systematic literature review. Med Care 2013;51:938-44.

25. Annual report 2014 [report in Dutch]. The Hague (The Netherlands): Regional Euthanasia Review Committees: 2015. Available: https://www.euthanasiecommissie.nl/de -toetsingscommissies/uitspraken/jaarverslagen/2014/nl/nl/ jaarverslag-2014 (accessed 2016 Sept. 2).

26. Oregon's Death with Dignity Act - 2014. Portland (OR): Oregon Public Health Division; 2015. Available: https://public.health. oregon.gov/ProviderPartnerResources/EvaluationResearch/Death withDignityAct/Documents/year17.pdf (accessed 2016 Jan. 21).

27. Washington State Department of Health 2014 Death with Dignity Act report: executive summary. Tumwater (WA): Washington State Department of Health; 2014. Available: www.doh.wa.gov/ portals/1/Documents/Pubs/422-109-DeathWithDignityAct2014 pdf (accessed 2016 Jan. 21)

28. Radbruch L, Leget CJW, Bahr P, et al. Euthanasia and physician-assisted suicide: a white paper from the European Association for Palliative Care. Palliat Med 2016;30:104-16.

29. Van Wesemael Y, Cohen J, Bilsen J, et al. Implementation of a service for physicians' consultation and information in euthanasia requests in Belgium. Health Policy 2012;104:272-8.

30. Jansen-van der Weide MC, Onwuteaka-Philipsen BD, van der Wal G. Quality of consultation and the project "Support and Consultation on Euthanasia in the Netherlands" (SCEN). Health Policy 2007;80:97-106.

31. Cohen J, Van Wesemael Y, Smets T, et al. Nationwide survey to evaluate the decision-making process in euthanasia requests in Belgium: Do specifically trained 2nd physicians improve quality of consultation? BMC Health Serv Res 2014;14:307.

32. Vanden Berghe P, Mullie A, Desmet M, et al. Assisted dying the current situation in Flanders: euthanasia embedded in palliative care. Eur J Palliat Care 2013;20:266-72.

33. On palliative care and euthanasia. Vilvoorde (Belgium): Federation of Palliative Care Flanders; 2013. Available: www.palliatief.be/ accounts/143/attachments/Publicaties/visietekst_onpalliativecare_ and_euthanasia_27_05_2013_def.pdf (accessed 2016 Jan. 15).

34. Van Brussel L, Van Landeghem P, Cohen J. Media coverage of medical decision making at the end of life: a Belgian case study. Death Stud 2014;38:125-35.

35. Smets T, Bilsen J, Cohen J, et al. Reporting of euthanasia in medical practice in Flanders, Belgium: cross sectional analysis of reported and unreported cases. BMJ 2010;341:c5174.

Affiliations: End-of-Life Care Research Group (Dierickx, Deliens, Cohen, Chambaere), Vrije Universiteit Brussel, Brussels, and Ghent University, Ghent, Belgium; Department of Medical Oncology (Deliens), Ghent University Hospital, Ghent, Belgium

Contributors: All of the authors were responsible for the study's conception and design. Sigrid Dierickx was responsible for data preparation and statistical analysis. Sigrid Dierickx, Kenneth Chambaere and Joachim Cohen drafted the manuscript. All of the authors critically revised the manuscript for important intellectual content, approved the final version to be published and agreed to act as guarantors of the work. Joachim Cohen and Kenneth Chambaere contributed equally as last author in the byline.

Funding: Kenneth Chambaere and Joachim Cohen are postdoctoral fellows of the Research Foundation - Flanders. This study was funded by internal resources.

Acknowledgements: The authors would like to thank the Belgian Federal Control and Evaluation Committee on Euthanasia for providing the database of all reported euthanasia cases. They also thank Jane Ruthven for providing assistance with linguistic editing. 